\title{
DESMITIFICACIÓN DEL LATIN LOVER HOLLYWOODIENSE EN LA TRILOGÍA NOVELESCA DE ENRIQUE JARDIEL PONCELA
}

CÉCILE François

Université d'Orléans

cecile.francois@univ-orleans.fr

\section{RESUMEN}

La trilogía novelesca de Enrique Jardiel Poncela deja transparentar la animadversión que experimenta el joven humorista hacia el Latin Lover, un nuevo tipo masculino aparecido en las pantallas de cine a principios de los años veinte, y encarnado idealmente por el famoso actor hollywoodiense Rodolfo Valentino. A lo largo de las tres novelas, el autor se vale de las principales características del nuevo mito para deslucir la imagen del Latin Lover y poner en solfa el Star System recién establecido por los grandes estudios hollywoodienses. El análisis resalta el arte con que Jardiel se vale de los recursos del humor, de la ironía, o de la caricatura para derrocar al ídolo de su pedestal.

Palabras Clave: Jardiel Poncela; Latin Lover; Rodolfo Valentino; Star System; desmitificación.

\section{RÉSUMÉ}

Dans sa trilogie romanesque, Enrique Jardiel Poncela laisse poindre l'agacement qu'il éprouve envers un nouveau type masculin récemment apparu sur les écrans au début des années 1920, celui du Latin Lover incarné idéalement par le célèbre acteur hollywoodien Rudolph Valentino. Au fil des trois romans, le jeune humoriste se saisit des principales caractéristiques de ce nouveau mythe afin de ternir l'image du Latin Lover et railler le Star System récemment mis en place par les grands studios hollywoodiens. L'analyse met en relief l'art avec lequel Jardiel se sert de l'humour, de l'ironie ou de la caricature pour faire tomber l'idole de son piédestal. 
Mots-CLÉs: Jardiel Poncela; Latin Lover; Rudolph Valentino; Star System; démystification.

En su trilogía «erótico-humorística» redactada y publicada a finales de los felices años $20^{1}$, Enrique Jardiel Poncela da fe de la afición del público español al cine y a la famosa «fábrica de sueños» hollywoodiense que suministraba a los espectadores su dosis semanal de ensoñación. A principios de la década apareció en las pantallas de los grandes cines de Madrid o Barcelona, un nuevo tipo masculino, el Latin Lover, encarnado idealmente en el actor de origen italiano, Rodolfo Valentino. El estreno de la película The Sheik (El Caíd), en 1921, significó el nacimiento de un mito hábilmente construido por los grandes estudios de cine y la prensa especializada. Aprovechando el impulso dado por Valentino, una constelación de galanes llamados Antonio Moreno, Ricardo Cortez o Ramón Novarro impusieron en las pantallas aquel tipo moreno y varonil que había de alimentar durante muchos años las fantasías del público femenino. Para un sinnúmero de mujeres encandiladas, el Latin Lover era realmente encantador o «irresistible», un adjetivo que Enrique Jardiel Poncela utiliza de manera continua en la trilogía, si bien en la primera acepción de la palabra, siendo para él ese tipo del amante latino un personaje harto «insoportable»o «insufrible» ${ }^{2}$.

\section{EL LATIN LOVER Y SU TRATO DENIGRANTE EN LA TRILOGÍA JARDIELESCA}

El lector de Jardiel Poncela repara en seguida en la irritación que siente el autor frente al Latin Lover y a la fascinación que este ejerce en las mujeres de la época. En su segunda novela larga, ¡Espérame en Siberia, vida mía!, publicada en 1929, Jardiel Poncela evoca a aquellos actores hollywoodienses que gozaban del privilegio de abrazar y besar a las estrellas más hermosas del Star System. «¿Qué mujer no ha soñado sentirse apretujada por Ramón Novarro?», se pregunta el narrador ${ }^{3}$ dando cuenta de la atracción del público femenino por este actor que acababa de triunfar en el papel de un seductor árabe ${ }^{4}$. Contra la opinión general y a pesar (o quizá a causa) del éxito mundial de The Arab, Jardiel Poncela no disimula el desprecio que siente por el intérprete principal de la película, poniendo bajo la pluma de su narrador esta definición perifrástica sumamente degradante: «Ramón Novarro (o alcaloide de la cursilería)» (Espérame: 252).

Es de notar que, para el humorista madrileño, la ridiculez no es privativa de Ramón Novarro. Ya en Amor se escribe sin hache, la primera novela del ciclo, el narrador había arremetido contra Rodolfo Valentino. Atlético, heroico, varonil, atractivo, este Latin Lover representaba para Luis Cernuda el tipo de la virilidad sublimada por Hollywood (Morris,

${ }^{1}$ La trilogía consta de tres novelas redactadas entre 1928 y 1930. Se titulan respectivamente Amor se escribe sin hache (1928), ¡Espérame en Siberia, vida mía! (1929) y Pero... ¿hubo alguna vez once mil vírgenes? (1930). Siempre que se citen estas novelas, será de forma abreviada (Amor, Espérame, Vírgenes).

2 Irresistible: 1- que no se puede resistir o tolerar; insoportable. 2- de mucho atractivo y simpatía (RAE).

${ }^{3}$ Roberto Pérez apunta al respecto que, si bien en su edición de la novela aparece el nombre de Clark Gable, en la primera edición de 1929 figuraba el de Ramón Novarro (Espérame: 252 y 482 nota 123).

${ }^{4}$ Novarro es la estrella protagonista de The Arab, una película de Rex Ingram fechada en 1924. Para María del Mar Mañas Martínez, Ramón Novarro fue uno de los primeros Latin Lovers del cine hollywoodiense (Mañas Martínez, 1997: 241). 
1993:131). Por supuesto, el poeta español discrepa rotundamente del narrador jardielesco, para quien los rasgos más característicos de Rodolfo Valentino son «[la] belleza y [la] cursilería sin igual» (Amor: 341). Como se echa de ver, la misma palabra sirve para designar tanto a Valentino como a Novarro. Para Jardiel Poncela, tal para cual, y el narrador de la trilogía envuelve a los dos Latin Lovers en el mismo desprecio.

Este trato indiferenciado puede resultarle extraño al lector moderno, para quien el nombre de Novarro no suena tanto como el de Valentino. Se explica sin embargo por la actualidad de la época, así como por el papel de la prensa que acostumbraba poner en un plano de igualdad a aquellos dos actores presentándoles, ora como los hermanos gemelos del erotismo cinematográfico, ora como dos rivales que se disputaban los favores de las mujeres. Cierto es que sus carreras cinematográficas parecían discurrir por caminos paralelos y el estreno en 1924 de The Arab, la película que consagró a Novarro, parecía una respuesta a The Sheik que algunos meses atrás había elevado a Valentino a rango de mito erótico. Jeanne de Recqueville, una de las biógrafas del actor, señala que, al estrenarse la película The Arab, un semanario norteamericano reunió a los dos Latin Lovers en una misma página partida en sentido longitudinal. A la derecha aparecía Rodolfo Valentino vestido de Caíd en tanto que, a la izquierda, Novarro venía retratado de igual modo y en la misma pose. En el centro, entre los dos, un enorme signo de interrogación seguía a una pregunta a medio formular: «Which one...?» («¿Cuál de los dos...?») (Recqueville, 1978:57).

Es obvio que el mito erótico del Latin Lover se benefició de la atmósfera sensual y lánguida de algunas películas ambientadas en un Oriente diseñado para satisfacer a un público ávido de aventuras escabrosas repletas de escenas tórridas llenas de pasión. Arabian Love, Fazil, The Son of the Sheik, Arabian Night, The Arab, en las pantallas de los años veinte se sucedían los filmes con decorados orientalizantes, pero ninguno de ellos tuvo el impacto de The Sheik, dirigido por George Melford y protagonizado por Rodolfo Valentino junto con Agnès Ayres y Adolphe Menjou. Rapto, besos apasionados, abrazos voluptuosos, todos los ingredientes estaban reunidos para escandalizar a la América puritana. Y mientras el senador Hays se deshacía en imprecaciones contra esa apología del desenfreno, las espectadoras (mucho menos ariscas) se entusiasmaban con aquel seductor oriental de ojos aterciopelados, soberbio, violento e indómito, que las hechizaba desde la pantalla.

Es precisamente esta representación de un Oriente de pacotilla, colmado de sensualidad y erotismo, la que recupera Jardiel Poncela para construir el decorado de las hazañas del donjuán de Pero... ¿hubo alguna vez once mil vírgenes? Lejos de abandonar sistemáticamente a las mujeres seducidas como lo hacía el Tenorio legendario, el protagonista de la novela ha recreado alrededor de su persona una especie de «harén moruno» ${ }^{5}$ en el que se comporta como un sultán o un bajá. Sus ex amantes, ahora convertidas en secretarias o en criadas del seductor, son mujeres rendidas de amor cuyo único propósito es agradar a su amo y cuya

5 Jardiel Poncela parece decantarse aquí por los defensores del concepto oriental del amor donjuanesco. Para Denis de Rougemont, por ejemplo, la apreciación que del amor y de las mujeres tiene Don Juan se opone rotundamente al amor cortés occidental, plasmado en el mito de Tristán e Isolda y basado en el culto exclusivo a la mujer amada. En cambio, Gregorio Marañón, a quien Jardiel Poncela dedica irónicamente su tercera novela, denuncia «el error de confundir el harén moruno con la clientela femenina de Don Juan» (Marañón, 1958: 90). 
mayor ilusión sería disfrutar otra vez, siquiera una hora, de sus favores. La presencia varonil del seductor disuelve las personalidades de esas mujeres que pierden su identidad y su categoría de seres humanos para convertirse en meros objetos de deseo, lascivos e insaciables, como sugieren las sinécdoques: «Ojos inefables le acariciaban. Labios abarrotados de besos se le brindaban al paso» (Vírgenes: 309).

En esta escena tórrida, Valdivia es plenamente consciente de su papel de amo. Sabe que domina a una corte de mujeres enardecidas y sometidas, entregadas en cuerpo y alma al «Caíd», y con la mente puesta en la realización de su menor deseo. El narrador no disimula su desprecio por ese donjuán de medio pelo, engreído y pagado de sí mismo, que se porta como un chalán, cuando no un semental, «caracole[ando] entre sus mujeres repartiendo sonrisas, pellizcando mejillas y manoseando gargantas» (Vírgenes: 309). Parte de ese desdén recae naturalmente en el grupo de las mujeres que aceptan, deslumbradas y agradecidas, ese tratamiento sumamente degradante. «Y Mercedes, la marquesita, Thérèse, Lulú y Alicia resplandecían de felicidad», comenta el narrador como si ellas solo vivieran pendientes de la llegada de Valdivia. Resulta significativo que las secretarias (lo mismo que las empleadas y sirvientas al final de la secuencia) solo aparezcan en grupos, siendo cada una un elemento intercambiable del conjunto, como da fe de ello el orden de aparición de sus nombres en las frases:

Alicia, la marquesita, Thérèse y Lulú, después de colgarse nuevamente del cuello de Pedro, se reintegraron a sus mesas. [...]

Alicia, Thérèse, la marquesita y Lulú habían levantado las cabezas y fijaban en el grupo sus pupilas coléricas. [...]

Detrás marchaban Thérèse, Lulú, Alicia y la marquesita, que jamás dejaban de salir a despedir a su amo hasta el automóvil (Vírgenes: 309, 310, 333).

El paralelismo frástico llama la atención del lector sobre la superioridad del seductor, presentado en su singularidad, frente al grupo compacto de unas mujeres de comportamiento similar, verdaderos objetos sexuales indiferenciados. Para las ex amantes de Valdivia, el placer y la voluntad del seductor tienen fuerza de ley y su deber es aguantarse y obedecer. « ¿Te he dado pie para esto? ¿No tenías bastante con los besos que os repartí al entrar?», así es como reconviene el seductor a una de sus secretarias por sus demostraciones excesivas de cariño (Vírgenes: 310 ). Verdadero tirano que tiene sojuzgadas a sus mujeres, Valdivia no necesita hablar ni actuar. Le basta con «una mirada helada» para imponerse y afianzar su posición de amo (Vírgenes: 311 ). Por supuesto, cualquier conato de rebelión, o por lo menos de resistencia, es sancionado por una exclusión inapelable, sin que Valdivia tenga que intervenir directamente en el asunto. Por lo contrario, igual que un bajá, él «aguard[a], repantigado en el sillón y lanzando al techo los chorros de humo en que se deshac[e] su abdulla» (Vírgenes: 311; énfasis del autor $)^{6}$.

${ }^{6}$ El narrador remite sin duda a la prensa de la época y a los rumores que aludían a la indolencia de Rodolfo Valentino y al hecho de que se pasara el tiempo tumbado en un sofá, o arrellanado en unas almohadas de seda, fumando cigarrillos aromáticos como los del Caíd (Walker, 1977: 82-83). 
Alexander Walker señala en su libro que Valentino tenía la reputación de ser un hombre de «virilidad amenazadora» (1977:91). En la película de Clarence Brown, The Eagle (El águila negra), rodada en 1927, el protagonista mira fría y arrogantemente a la heroína a quien acaba de raptar, mientras va echando unas ojeadas significativas a la fusta que lleva en la mano (Walker, 1977:99). Esta es la imagen que recupera el narrador de Pero... ¿hubo alguna vez once mil vírgenes? cuando retrata a Valdivia como un domador de fieras, aunque la intención es aquí claramente desmitificadora: «Entonces se volvió [...], como se vuelven hacia el público los domadores cuando han conseguido meter la cabeza en las bocas de sus tigres sin que a los tigres les entren náuseas» (Vírgenes: 312 ).

A buen seguro, la visión de este donjuán inflexible y omnipotente, que se pavonea en su serrallo entre una nube de mujeres extasiadas y lascivas, podría abrir un horizonte de expectativas similar al de la película The Sheik. Sin embargo, el lector se siente rápidamente defraudado ya que Valdivia no tiene ni el encanto ni la sensualidad de Rodolfo Valentino. Al contrario, a lo largo de la escena, aparece como un seductor rutinario y laborioso, totalmente indiferente a la atmósfera electrizante que lo rodea. En realidad, Valdivia se resigna a desempeñar el papel de mito erótico que encarna para sus ex amantes y actúa sin entusiasmo alguno, como si cumpliera un especie de deber conyugal: «no [tengo] más remedio que ir besando aquellos labios», «lo hago solamente para estimularlas al trabajo», manifiesta con tono cansino (Vírgenes: 309).

Estas nociones de deber y esfuerzo nos alejan del brío y la sensualidad del Caíd. Frío y distante, el seductor jardielesco se preocupa ante todo por borrar a conciencia las señales que delatan el ardor de sus mujeres, «[absorbiéndose] cuidadosamente las huellas de rouge de que los sucesivos besos le habían embadurnado» (Vírgenes: 309). Por supuesto el léxico escogido, y en particular el verbo «embadurnar» participa de la degradación de la imagen erótica del seductor, frustrando así las expectativas del lector (y de la lectora). La visión final que conservamos de Valdivia es, no ya la de un amo, sino de un maestro de escuela que llama al orden a sus alumnos (o, lo que tal vez sea más adecuado, la de un jefe de sección animando a sus empleados): «A continuación se puso serio. Dio una palmada y exclamó: ¡Ea! Y a trabajar..., que el tiempo vuela...»(Vírgenes: 309$)^{7}$.

No cabe duda de que Enrique Jardiel Poncela arremete en Pero... ¿hubo alguna vez once mil vírgenes? contra los tópicos del cine hollywoodiense, y en particular contra todas aquellas películas exóticas con fondo de harén moruno que nutrían las fantasías eróticas del espectador de la época. La escena central de la visita de Valdivia a sus secretarias constituye una brillante parodia que recoge, para mejor subvertirlos, una parte de los estereotipos alrededor de los cuales se fabricaban esos filmes. Jardiel Poncela parece seguir aquí los pasos de Mack Sennett, uno de los más celebrados maestros del cine burlesco, quien había ofrecido un poco antes, a los espectadores, un divertido cortometraje titulado The Shriek of Araby, como

${ }^{7}$ El hallazgo de Jardiel Poncela consiste en hacer que se solapen las dos imágenes contradictorias del harén y de la oficina como si hubiera querido llevarle la contraria al doctor Marañón, para quien Don Juan «no es el sultán que organiza du poligamia como si fuera una oficina» (citado por Luis Alemany, 1988: 318). 
respuesta a la famoso película The Sheik ${ }^{8}$. Lo que pretendía Sennett era mofarse de aquellas películas exóticas y arruinar el prestigio de Rodolfo Valentino, desbaratando su mito. Pues bien, esa es precisamente la meta que persigue Enrique Jardiel Poncela cuando pone en escena un trasunto de Valentino al que retrata bajo la forma de un sultán indolente y rutinario en el extremo opuesto del Caíd arrojado y sensual encarnado por el actor hollywoodiense.

Nada impide pensar que, además de The Sheik, Jardiel haya tenido la mente puesta en la última película de Valentino, titulada The Son of the Skeik (El hijo del Caíd), rodada algunas semanas antes de la muerte del actor, en la que se aprovechaban los mismos ingredientes, si bien con una innovación importante, señalada por Alexander Walker, en lo que concierne a la «psicología erótica». En efecto, la seducción de la bailarina por el hijo del Caíd no se lleva a cabo por amor sino por odio y venganza (Walker, 1977:102-103). Valdivia comparte con el personaje cinematográfico la misma concepción de la conquista amorosa. La idea de venganza nace en él a raíz de una promesa hecha a su tío al que una amante desairada acaba de clavarle un puñal en la espalda. En su lecho mortuorio, don Félix le pide a Valdivia que le jure que vaya a dedicar su vida a enamorar mujeres y a abandonarlas cuando más enamoradas estén (Vírgenes: 234). La muerte del tío representa una especie de trauma para el sobrino, provocando un viraje decisivo en su carrera. A partir de ese momento, Valdivia vivirá con la mente puesta en la venganza y el cumplimiento de su promesa: «Vengaré tu muerte enamorando a todas las mujeres que encuentre en mi camino; pero primero he de vengarte enamorando a la mujer que te mató» (Vírgenes: 236).

Es de notar que esta idea se convierte rápidamente en una verdadera obsesión ya que, tras la seducción de Silma Drake y su consiguiente destrucción, Valdivia no se siente aliviado. En adelante, su deseo de venganza se extiende a todas las mujeres que se convierten en enemigos potenciales a los que hay que vencer y castigar. Jardiel acentúa de manera caricaturesca los rasgos del modelo cinematográfico puesto que, si el hijo del Caíd tiene ansias de venganza, estas van dirigidas contra una sola mujer a la que culpa de haberle engañado. Valdivia, en cambio, se erige en vengador universal.

\section{LA RIDICULIZACIÓN DEL CULTO AL ÍDOLO}

A todas luces, sea Valentino en The Sheik, Ramón Novarro en The Arab, o cualquier otro actor que lo represente, el Latin Lover nunca logra caerle en gracia al narrador, quien multiplica las pullas y mofas para desprestigiarlo y reírse del culto desmesurado que se le rendía. En Amor se escribe sin hache, la primera novela de la trilogía fechada en 1928, Jardiel Poncela arremete contra Adolphe Menjou, un actor especializado en papeles de dandi aristocrático con personalidad arrolladora9 ${ }^{9}$. Por cierto, el novelista madrileño no era el único en

${ }^{8}$ Este filme paródico, rodado en 1923, se estrenó en España con un título vertido al castellano, El alarido de Arabia, el cual, si bien mantenía el sentido de la palabra inglesa «Shriek», eliminaba el juego de palabras basado en la paronimia Sheik / Shriek..

${ }^{9}$ Entre los numerosos títulos de la filmografía de Adolphe Menjou, algunos resaltan la superficialidad y liviandad que caracterizaban a los personajes que solía encarnar. Recuérdense en particular dos películas rodadas respectivamente en 1923 y 1924: A Woman of Paris de Charlie Chaplin y The Marriage Circle, una película de Lubitsch cuyo título español es Los peligros del firt. 
criticar a este famoso Latin Lover. Por aquel entonces, Francisco Ayala denunciaba también el trabajo del actor que, según él, «sab[ía] a folletín y a casino. A teatro». El escritor añadía que «Menjou [era], en definitiva, eso: un actor de teatro ligero, sentimental y vacío, aferrado a las buenas maneras y a los vestuarios complicados» (Ayala, 1996:37-38). Por su parte, en La acogedora oscuridad, Brian C. Moris nos habla del desprecio que sentía Rafael Alberti hacia el tipo de personaje encarnado por Adolphe Menjou con su «dulce bigote apasionado», a la par que resalta la crítica que hacía el poeta del universo mundano, vano y superficial en que se desenvolvía el actor en muchas de sus películas (Morris, 1993:118).

El narrador de Amor se escribe sin hache no les va la zaga cuando, al principio del relato, describe con fina ironía uno de los numerosos lances amorosos del protagonista que se verifica precisamente en el «Cine Menjou», «palacio del celuloide erigido en honra de dicho actor» (Amor: 145). Esta elección da a los amoríos del héroe un toque de elegancia y refinamiento a la par que abre un horizonte de expectativas muy prometedor, aunque este no tarda en modificarse según el universo de la comedia sofisticada se va convirtiendo en una escena típica del cine cómico mudo. Ante los ojos del lector atónito, la dulce protagonista, a la que el narrador había venido designando a lo largo del capítulo como «la mujer romántica» por antonomasia, resulta ser una feroz pugilista que convierte la romanza en batalla campal de la que el pobre protagonista sale muy malparado: «Un día [Ramona] se me llevó un trocito de oreja, una tarde se quedó con medio labio y una noche me arrancó al besarme en el brazo toda la manga del "smoking"» (Amor: 147).

En la secuencia dedicada al cine, Jardiel Poncela aprovecha también la ocasión para mofarse del culto que se les rendía a las grandes estrellas del cine de Hollywood, un culto fabricado por el Star System con finalidad puramente económica. «Hemos edificado la industria cinematográfica en la star», solía repetir Adolph Zukor, el fundador de la Paramount Pictures (Bosseno \& Gerstenkorn, 1992:26). Para él, igual que para la mayor parte de los directores de los grandes estudios de cine, la mención en los créditos o en los carteles de un nombre famoso era una de las claves del éxito de una película. Además de los esfuerzos financieros realizados por los productores para promover a sus estrellas, se publicaban cientos de artículos, fotos, entrevistas que participaban eficazmente en el desarrollo del Star System. Gracias a la acción conjunta de la Prensa y de los Estudios, el actor se convirtió así en una especie de ídolo entregado al culto de miles de admiradores que se rifaban sus «reliquias». De hecho, la muerte de famosísimo Rodolfo Valentino provocó una verdadera histeria colectiva, siendo una ganga para los centenares de falsificadores que fabricaron pseudo-reliquias a montones: cordones de zapato, pañuelos, gemelos y demás cosas que pasaban por ser objetos personales del ídolo (Recqueville, 1978:222).

Esta situación novedosa para la época merece un tratamiento irónico en Amor se escribe sin hache, cuando el narrador escribe que cada espectador del Cine Menjou recibía, además de su entrada, «un pelito del bigote de Adolfo conservado en virutas» (145). No cabe duda de que Jardiel Poncela se divierte a costa de esos admiradores ingenuos que se entregaban a la contemplación, cuando no a la veneración, de cualquier objeto que perteneciera a sus ídolos, por muy nimio que fuese. La ridiculización alcanza aquí su punto álgido con el regalo de esos pelos de bigote cuya abundancia no deja de sorprender ya que, si realmente el apuesto Menjou tuviera que satisfacer a sus millones de admiradores suministrándoles tantos 
pelitos como necesitasen, ya no tendría la oportunidad de lucir ese «dulce bigote apasionado» que enamoraba a las mujeres. Para acentuar la burla, un comentario irónico entrecomillado («idelicado presente!») denuncia mediante una antífrasis lo dudoso de aquellas operaciones publicitarias y la credulidad de tantos papanatas.

La ridiculización del culto al ídolo se advierte también en Pero... ¿hubo alguna vez once mil vírgenes?, el tercer volumen de la trilogía. En dicha novela, nada sorprende tanto al lector como el papel desempeñado por una barba en la escena de la ruptura de Valdivia y Vivola Adamant. De hecho, para la protagonista, el que su amante se haya afeitado pasa a ser «un drama, un verdadero drama» (Virgenes: 487). Cierto es que una reacción tan inverosímil por una barba que el seductor lleve o deje de llevar puede leerse como un ejemplo más de la misoginia de Jardiel Poncela y de su gusto por demostrar cuán volubles y superficiales son las mujeres. Pero esta explicación no puede satisfacer al lector asombrado por la presentación hiperbólica de un hecho tan intrascendente. Además, ¿cómo justificar una reacción tan desproporcionada en un personaje acostumbrado, a lo largo de su dilatada carrera de mujer fatal, a las mayores excentricidades?

El lector no comprende en absoluto por qué Vivola «estalló en sollozos desgarrados y sinceros» al descubrir que Valdivia se había afeitado la barba (Vírgenes: 469). Tampoco entiende cómo una acción tan insignificante puede merecer tal desencadenamiento de furor y rabia: «iiVete, imbécil!! ¡iVete!! Te desprecio... Te odio... [...] ¡Fuera de aquí! ¡iFuera!! Que yo no te vea jamás... ¡Jamás! ¡iJamás!!» (Vírgenes: 469). El rechazo definitivo de Valdivia por Vivola Adamant resulta totalmente absurdo en este contexto, ya que el motivo del furor y de la desesperación de Vivola no es nada irreversible y bien podría remediarse en dos o tres días. En estas condiciones, ¿cómo explicar que un hecho tan baladí pueda constituir semejante trauma, dejándola «pálida, lívida, afrentada, como una hija del Cid en el robledal de Corpes» (Virgenes: 469)? ${ }^{10}$

Quizá sea posible descifrar el enigma y entender esta situación desconcertante (cuando no absurda) si recordamos el clamor de indignación que provocó en América la caracterización de Rodolfo Valentino durante el rodaje de The Hooded Falcon. Para encarnar a un guerrero moro de la época del Cid, el famoso actor, a la inversa del seductor jardielesco, había tenido que dejarse crecer la barba. Acto seguido, se formaron dos bandos entre los admiradores de Valentino. Por una parte, aquellos incondicionales que imitaban en todo a su ídolo y guardaron inmediatamente su navaja de afeitar en un cajón y, por otra, todas aquellas mujeres prendadas del rostro afeminado del actor, quienes protestaron con vehemencia exigiendo que Valentino recobrase su aspecto anterior. Al fin y al cabo el revuelo causado por ese incidente dejó una impronta mayor en la historia del cine que la propia película que lo había generado, la cual en definitiva no llegó a estrenarse.

En Pero... ¿hubo alguna vez once mil vírgenes?, Jardiel Poncela se mofa también de la extraordinaria popularidad de que gozaba Valentino. Igual que el mítico actor, el protagonista de la novela tiene que aguantar el acoso de sus admiradores que lo aclaman con delirante

${ }^{10}$ Cabe notar que Valdivia no sale mejor parado del lance ya que en adelante vivirá obsesionado por «aquella barba afeitada [que] danza [...] ante sus ojos un vals vienés, diciéndole: — ¡fracasaste por... por mi culpa! ¡iPor culpa de una barba!!» (Vírgenes: 486). 
entusiasmo. Su llegada a la estación de Niza se verifica entre vivas y aclamaciones, como demuestran las hipérboles siguientes: «ovación entusiasta», «ovación estruendosa», «arroba y media de vítores». Al mismo tiempo, los comentarios del narrador se suceden para describir la atmósfera de fervor y júbilo que rodea a Valdivia: «Y muchas manos se tendieron ávidas de apretones. Valdivia se asomó y estrechó manos de hombres y besó manos de mujer. Un coro de saludos en cinco idiomas» (Vírgenes: 383). El entusiasmo, con todo, no es unánime puesto que el público masculino no ve siempre con buenos ojos los estragos que causa entre sus compañeras la presencia del seductor. Alexander Walker da fe de la animadversión que sentían los hombres para con Valentino, a ejemplo de este periodista de Photoplay que dejaba estallar su rabia en abril de 1922:

¡Odio a Valentino! ¡Todos los hombres lo odian! ¡Odio su comportamiento oriental! [...] ¡Odio su sonrisa, sus dientes brillantes, odio su pelo engominado! [...] ¡Lo odio porque es el gran seductor de la pantalla! ¡Lo odio porque conquista corazones, lo odio porque es demasiado avezado en el arte de la seducción! [...] ¡Lo odio porque es demasiado guapo! ${ }^{11}$

Tomando el relevo, el periodista francés, André Daven, ratificaba este dictamen inapelable algunos meses después: «La popularidad de Rodolfito desafía la imaginación pero bien veo que aquí los hombres lo odian porque las mujeres se mueren por él» ${ }^{12}$. En Pero... ¿hubo alguna vez once mil vírgenes?, Jardiel Poncela deja constancia de esta discrepancia de opiniones y actitudes dentro del público, procurando plasmarla gráficamente. A la salida del teatro, Valdivia, acompañado de una rubia hermosa, suscita una multitud de comentarios que el narrador simplifica y resume con el esquema siguiente:

\begin{tabular}{|c|c|c|c|}
\hline \multicolumn{2}{|c|}{ LAS MUJERES DIJERON } & \multicolumn{2}{|c|}{ LOS HOMBRES DIJERON } \\
\hline $\begin{array}{l}\text { Refiriéndose a } \\
\text { Valdivia: }\end{array}$ & $\begin{array}{l}\text { Refiriéndose a } \\
\text { a la rubia: }\end{array}$ & $\begin{array}{l}\text { Refiriéndose a } \\
\text { Valdivia: }\end{array}$ & $\begin{array}{l}\text { Refiriéndose a } \\
\text { a la rubia: }\end{array}$ \\
\hline $\begin{array}{l}-i E s \\
\quad \text { guapísimo! }\end{array}$ & $\begin{array}{c}\text { - iEs una } \\
\text { facha! }\end{array}$ & $\begin{array}{r}-i \text { iEs un } \\
\text { idiota! }\end{array}$ & $\begin{array}{l}\text { - iEs } \\
\quad \text { estupenda! }\end{array}$ \\
\hline
\end{tabular}

Figura 1. (Vírgenes: 342).

\section{RODOLFO VALENTINO, «EL AMANTE UNIVERSAL»}

Quizás lo que más irritase a los hombres fuese la fascinación erótica que despertaba en las mujeres Rodolfo Valentino, al que todos llamaban en aquel entonces «el Amante Uni-

\footnotetext{
11 «Je hais Valentino! Tous les hommes le haïssent! Je hais son comportement oriental, je hais son nez classique, je hais son visage romain! Je hais son sourire, ses dents brillantes, je hais ses cheveux gominés, je hais son air de Svengali! Je le hais parce qu'il est le grand séducteur de l'écran, je le hais parce qu'il enflamme les cœurs, je le hais parce qu'il est trop habile dans l'art de séduire, je le hais parce qu'il est le héros de Gloria Swanson! Je le hais parce qu'il est trop beau!» (Walker, 1977:70-71).

12 «La popularité de Rudy dépasse toute imagination mais les hommes, ici, je le vois bien, le détestent car les femmes en sont folles» (Recqueville, 1978:90).
} 
versal». Cierto es que, para las miles de admiradoras que se precipitaban a cada actuación pública de su ídolo con la ilusión de verle —y ser vistas o notadas por él—, el actor era una reencarnación del mítico Don Juan a quien todas rendían un auténtico culto. De hecho, fue en 1922, después de su doble triunfo en las películas The Sheik y Blood and Sand (Sangre y arena), rodadas respectivamente por George Melford y Fred Niblo, cuando nació realmente el mito que había de hacer de Rodolfo Valentino «el mayor seductor de la pantalla» ${ }^{13}$. A partir de allí, aparecieron una serie de parodias entre las cuales destaca, no solo The Shriek of Araby arriba mencionado, sino Mud and Sand, una hilarante versión del melodrama taurino en la que Stan Laurel interpreta el papel de un personaje llamado Rhubarb Vaselino (Tessé, 2007:32). En su trilogía, Enrique Jardiel Poncela nos propone a su vez una versión sumamente paródica del gran «mito erótico moderno», particularmente en Pero... ¿hubo alguna vez once mil vírgenes?, la última entrega subtitulada «La novela del donjuanismo moderno» y protagonizada por un seductor que comparte muchas de las características del actor hollywoodiense. En el «Ensayo n. ${ }^{\circ} 27.493$ sobre Don Juan», que encabeza el relato de las aventuras de Valdivia, Jardiel Poncela procura explicar el fabuloso éxito del Tenorio:

Sin anunciarse, sin que su fama corra de boca en boca, sin que todo el mundo se haga lenguas de lo seductor que es, Don Juan no conquistaría más que alguna que otra de esas muchachas de la clase media que gimen sofocadas por el hervor de casarse.

Pero Don Juan se anuncia; camina precedido de una nombradía extraordinaria, y las mujeres se lo rifan. Y Don Juan se deja rifar por las mujeres [...] (Virgenes: 110).

Este destino extraordinario es precisamente el de Rodolfo Valentino. En los años veinte, gracias a los incontables recursos ideados por los productores de Hollywood para convertir a sus actores en estrellas, Valentino - junto con Douglas Fairbanks, Greta Garbo, o Marlene Dietrich - aparecía aureolado de un prestigio inaudito. Su renombre se debía, entre otras cosas, a las numerosas campañas publicitarias y a la difusión mundial de sus películas con los correspondientes carteles esparcidos a lo largo y ancho del mundo. Cada aparición pública del actor provocaba gran alboroto. La gente se precipitaba para verle entrar o salir, abalanzarse sobre él y arrancarle, a ser posible, algunos botones de su chaqueta para llevárselos como reliquias (Recqueville, 1978:135). El fervor del público femenino se manifestaba, no solo en el momento de la aparición del actor en las pantallas o durante un acto solemne, sino a través de los centenares de cartas que le llegaban a diario. Según parece, Valentino batía todas las marcas en este terreno puesto que Roger Prédal menciona la cifra de unas cinco mil cartas semanales (Recqueville, 1978:215) ${ }^{14}$.

Es este aspecto del mito, muy moderno para la época, el que se evoca en Pero... ¿hubo alguna vez once mil vírgenes? (François, 2013:122-23). Ya al principio del relato, en la primera página de la secuencia titulada «Las doce últimas cartas del día», el narrador llama la atención en el correo del seductor cuya descripción viene enfatizada por un dibujo:

${ }_{13}$ Rafael Utrera considera que, gracias al rodaje de Sangre y arena, Rodolfo Valentino «llega a su apogeo de amante universal» en 1922 (Utrera, 1985:108).

${ }^{14}$ Alexander Walker, por su parte, reduce la cifra a un millar de cartas por semana, lo cual ya puede considerarse una cifra astronómica (1977:60). 
Eran doce sobres — verdes, azules, rosa, beige — en los que diferentes manos de mujer habían escrito idéntico nombre con grafismos parecidísimos:

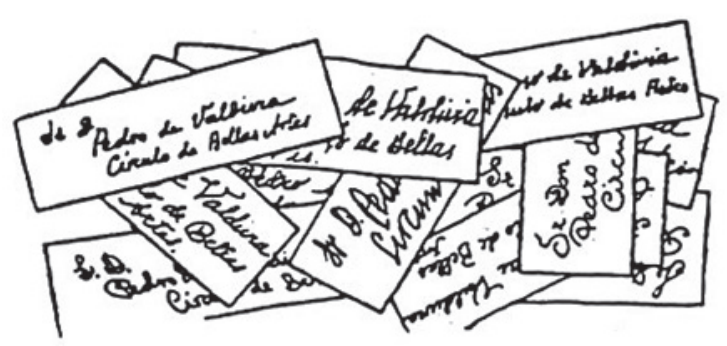

Figura 2. (Virgenes: 125).

A lo largo de la primera secuencia, las doce cartas iniciales van cobrando proporciones gigantescas, gracias a la intervención de diversos comentaristas que hacen cábalas acerca del volumen exacto de dicho correo. El primero en intervenir es el joven Luis Campsa, un ferviente admirador de Valdivia cuyas hazañas pondera del modo más hiperbólico: «[Valdivia] en su casa, tiene cartas de amor en cantidad suficiente para abarrotar un vapor correo» (Virgenes: 131). A uno de los contertulios se le ocurre entonces pasar a efectuar una serie de cálculos estrafalarios, cuyo resultado es sumergir a sus oyentes (y al lector) bajo una avalancha de cifras:

Y el general Schneider, muy dado al cálculo, arguyó:

- Pues doce aquí; veinticuatro en su casa; cien en el apartado y treinta en la Lista de Correos, suman ciento sesenta y seis... ¿Es posible que un hombre pueda recibir ciento sesenta y seis cartas de amor todos los días? Tenga usted en cuenta que al mes resultan cuatro mil novecientas ochenta, $\mathrm{y}$ al año sesenta mil quinientas noventa, $\mathrm{y}$ al...

Pero Luis Campsa, interrumpiéndole, le impidió calcular las cartas que resultaban al siglo. (Vírgenes: 132).

A raíz del triunfo de la película The Sheik, Rodolfo Valentino recibió, según sus biógrafos, unas diez mil peticiones de mano procedentes del mundo entero y de todos los estamentos de la sociedad: secretarias, vendedoras, duquesas o ricas herederas. Así las cosas, ¿cómo contestar a esta avalancha de cartas sin gastar en ello varias horas diarias? Los productores de Hollywood ya se habían planteado el problema y, desde el principio del Star System, idearon una estrategia destinada a satisfacer al público, aliviando al mismo tiempo a sus estrellas del peso de tamaña faena. Bastaba, para contentar a las miles de admiradoras y ganar tiempo, con mandarles una fotografía que ostentase una dedicatoria de su ídolo ${ }^{15}$. Acosado por miles de mujeres enamoradas, sumergido por toneladas de cartas, el protagonista de Pero... ¿hubo alguna vez once mil vírgenes? no tiene más remedio que recurrir a este sistema, como da fe

15 En su libro, Jeanne de Recqueville señala que la Ritz-Carlton Pictures Inc. usaba papel de carta con este membrete estampado arriba, a la izquierda: «Office of Mr. Rudolph Valentino» (1978:88). 
de ello el retrato que preside el escritorio de cada una de sus secretarias (François, 2013:122). El autor insiste en el carácter mecánico del procedimiento colocando una tras otra una serie de fotografías que normalmente deberían aparecer en distintos sitios de la sala:

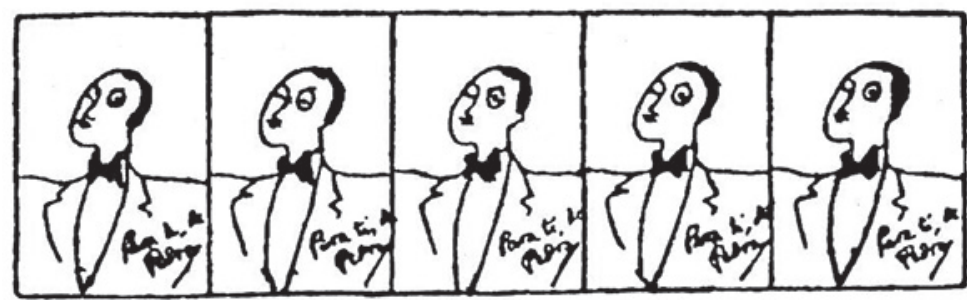

Figura 3. (Virgenes: 308).

Esmoquin con solapas de raso, camisa blanca y pajarita negra, esta es precisamente la ropa que vestía Rodolfo Valentino durante la última gira promocional de su película El hijo del Caíd en 1926, algunos meses antes de su muerte. También esta vestimenta es la que llevaba puesta en sus funerales para que sus admiradoras se llevasen para siempre aquella imagen de elegancia y distinción con la que conquistó al público.

Elevado a rango de estrella internacional al principio de la década de los años veinte, el famoso actor tenía a su disposición dos secretarios personales cuyo único trabajo consistía en despachar su voluminosa correspondencia. En la trilogía, Enrique Jardiel Poncela recoge este dato para amplificarlo de manera humorística. Su protagonista también tiene una oficina, o mejor dicho varias oficinas, donde trabaja media docena de empleadas encargadas de la redacción de su correspondencia. Valdivia se contenta con firmar las cartas previamente copiadas por sus secretarias, según modelos correspondientes a cada caso particular ${ }^{16}:$ «Con este fichero - explica Valdivia - el trabajo de contestar mi correspondencia se simplifica hasta el colmo» (Virgenes: 316). En esta secuencia, el lector descubre, incrédulo, el método imaginado por Valdivia para conseguir la máxima eficacia y rentabilidad valiéndose de los principios del taylorismo (François, 2013:123). De hecho, en las oficinas del seductor, nada se deja al azar y Thérèse, la secretaria particular de Valdivia, se encarga de perfilar el trabajo perfumando y sellando cada carta «con una barrita de rouge de los labios» (Virgenes: 317 ).

\section{EL HUMOR CORROSIVO COMO ARMA PARA DERROCAR AL ÍDOLO DE SU PEDESTAL}

La larga secuencia central, dedicada a un seductor cortado con el patrón del mítico actor, muestra a las claras la obsesión de Jardiel por el tipo cinematográfico del Latin Lover. Cierto es que la trilogía fue redactada en plena «valentomanía» y es precisamente esa idolatría la que pone en solfa el narrador jardielesco a lo largo de su relato. A finales de los años veinte,

16 «Yo me limito a señalar el número que corresponde de respuesta a cada carta que hay que contestar, y las mecanógrafas sólo tienen que copiar el modelo correspondiente...» (Vírgenes: 316 ). 
el nombre del actor era mundialmente conocido. Todos conservaban intacto el recuerdo del «seductor más famoso de la pantalla», cuya muerte prematura dos años atrás había causado la estupefacción, cuando no la desesperación, de sus miles de admiradores. El comportamiento histérico del público durante los días que precedieron a las exequias ha de verse, según Jeanne de Recqueville, como el símbolo de las relaciones malsanas que se pueden establecer entre una estrella y su público (Recqueville, 1978:165). En tales circunstancias no resulta extraño que la trilogía de Enrique Jardiel Poncela deje constancia, en tono irónico por supuesto, de esa pasión enfermiza y de aquel culto al ídolo llevado al extremo.

En Pero... ¿hubo alguna vez once mil vírgenes?, lo que provoca la desesperación de las mujeres no es la muerte del amante sino su insensibilidad y su cinismo. Durante la visita de las oficinas, Luis Campsa, el joven admirador de Valdivia, presencia el despido de Mercedes, la secretaria particular de Valdivia, castigada por no haber sabido reprimir los apasionados impulsos de su corazón. Excluida definitivamente del ámbito de su ídolo, ella desaparece del relato y el lector ignora cuál será su suerte. Quizás vaya a engrosar las filas de las ex amantes del donjuán hundidas en la desesperación y abocadas al suicidio. En el momento en que dejan las oficinas, Valdivia y Campsa presencian una escena que conmociona al joven admirador: con gesto desafiante, una mujer toma al seductor como testigo de su suicidio:

Y esta dama esperó que el coche estuviera a su lado para clavar en Valdivia una mirada terrible y para gritarle:

$-¡$ Asesino! lotería.

Luego alzó su mano derecha, se aplicó la pistola a la sien, disparó y cayó como un premio de

El auto siguió adelante.

- ¡Se ha suicidado! ¿No lo ha visto usted? ¡Se ha suicidado! - gritó Luisito Campsa retorciéndose para observar tras la mirilla trasera del coche (Vírgenes: 334 ).

Por supuesto, el símil «cayó como un premio de lotería» desactiva parte de la carga trágica de la escena. Por lo demás, la actitud del narrador parece coincidir con la del seductor frío e indiferente, quien se contenta con responder con desenvoltura, aplicando el encendedor eléctrico a su cigarrillo: «Sí. Ya lo he visto [...]. Es la séptima que se me suicida este mes» (Vírgenes: 334). A pesar del cinismo con que Valdivia comenta el drama, el dativo ético señala el interés del cazador por un nuevo trofeo que añadir a su lista. Además, el adjetivo numeral deja suponer que dicha lista no está cerrada y que Valdivia acepta de antemano, con una pizca de orgullo y satisfacción, esa hecatombe que debe de considerar como un homenaje o un culto rendido a su persona. Quizá pueda interpretarse esta escena como una alusión irónica a lo que los periódicos han llamado «la ola de suicidios» acaecidos a raíz de la muerte de Rodolfo Valentino en $1926^{17}$, aunque en la trilogía el gesto fatal se lleva a cabo en presencia de Valdivia para mejor resaltar el cinismo del seductor.

17 Datos sacados del libro de Jeanne de Recqueville, quien por su parte habla de una docena de suicidios y un centenar de tentativas sin desenlace fatal (1978:175). 
En Pero... ¿hubo alguna vez once mil vírgenes?, si bien «la ola de suicidios» no se relaciona con la muerte de Valentino, el narrador no deja de evocar abiertamente el cadáver del mítico actor al principio de la tercera parte, aprovechando la oportunidad que le proporciona la descripción del dormitorio de Valdivia: «Allí estaba el gong repujado, que en su cara anterior ostentaba bajorrelieves representando el triunfo de Alejandro en Persépolis, y en su cara posterior, la autopsia de Rodolfo Valentino» (Vírgenes: 273). La elección de este detalle del decorado es interesante porque permite al narrador, sin necesidad de explayarse, presentar a Rodolfo Valentino como un antihéroe. En efecto, lo que llama la atención es que el actor ha sido relegado a la cara posterior del gong mientras que la cara anterior (la principal) ostenta una de las más prestigiosas figuras de la Historia en el apogeo de su poder y de su triunfo, la de Alejandro Magno.

En realidad, nada impedía que se estableciese un paralelismo entre los dos personajes representando al Valentino gallardo e imperioso de la película The Sheik cuyos fotogramas habían dado la vuelta al mundo. Pero esto significaría colocar a Rodolfo Valentino y a Alejandro Magno en un plano de igualdad. Por el contrario, Jardiel Poncela escoge la figura inversa al paralelismo, es decir la antítesis, merced a la cual nos ofrece una imagen invertida y por tanto degradada del ídolo. Mientras Alejandro Magno se alza triunfante entre las ruinas de Persépolis, Rodolfo Valentino yace en una mesa de disección. Cabe señalar que Jacqueline de Recqueville afirma que el proyecto de autopsia había sido voluntariamente descartado para no menoscabar la imagen y el prestigio de Valentino y para que los miles de admiradores que habían acudido a inclinarse ante sus restos mortales se llevasen un recuerdo inalterado del ídolo ${ }^{18}$. Obviamente, en la novela de Jardiel, esta tergiversación de la verdad histórica asesta un golpe fatal al mito, al que vacía de su sustancia, al tiempo que lo despoja de su aura de seducción y misterio. No cabe duda de que el escalpelo del forense le sirve al narrador par dar un paso más en el proceso de deconstrucción de la figura del seductor latino llevado a cabo a lo largo de la trilogía.

Por supuesto, no es esta la única vez en que se menciona directamente el nombre del famoso actor en la trilogía. En su primera novela, Amor se escribe sin hache, Jardiel Poncela le dedica una secuencia entera maliciosamente titulada: «Los piscis Rodolphus Valentinus» (340-341). La escena se verifica poco después del naufragio de los dos protagonistas de la novela. En la isla en que los «robinsones» intentan organizar su nueva vida, el protagonista imagina una manera de capturar los peces que se mueven por bancos a lo largo de la orilla. Estos, aunque destinados a ser consumidos sin más ni más, no son meras sardinas o caballas sino bonitos peces exóticos llamados «Rodolphus Valentinus». A todas luces, esta es una invención puramente jardielesca, pero el narrador finge creer en su existencia atestiguando que aquellos peces habían sido debidamente catalogados, clasificados y registrados bajo un nombre latino por la comunidad científica.

El interés de esta denominación es doble. Primero, permite que, de manera sutil, el narrador recuerde los orígenes latinos del actor que encarnaba idealmente el tipo del Latin Lover. Por otra parte, así presentado, el mítico seductor se desesencializa. Es de pensar que,

${ }^{18}$ Alexander Walker apunta que los periódicos publicaron una foto de Valentino en el quirófano algunas horas antes de su muerte, pero no alude a una posible autopsia (1977:118). 
para Jardiel, Valentino no es sino un Latin Lover más, sin relevancia alguna. A lo sumo, será el prototipo, el patrón con el que se cortó el nuevo tipo masculino que se iba desdoblando y multiplicando en las pantallas según un proceso de clonación. Esta es la razón por la cual, en la novela, el narrador no lo individualiza sino que lo designa de forma genérica con el marbete: «piscis Rodolphus Valentinus», con lo cual viene confundido con la multitud de sus congéneres. De este modo, Jardiel logra no solo vulnerar la imagen de Rodolfo Valentino sino subvertir también el mito, puesto que parte de la esencia de este se fundamenta en el concepto de unicidad. Para todos, Valentino es, en efecto, $E l$ seductor universal, la encarnación de Don Juan, El mito erótico por antonomasia. Como advierte Jeanne de Recqueville, nadie ha podido sustituirlo pese al número impresionante de pretendientes al título.

El nombre así latinizado confiere también a la presentación del Latin Lover un marchamo científico. Con esta designación culta el narrador logra equiparar al actor con un bicho raro, un espécimen valioso digno de figurar en los museos, un objeto de contemplación para los estudiosos del mundo entero. Cierto es que Rodolfo Valentino encarna «El Misterio insondable» del mito, siendo este un tema de análisis y de reflexión inagotable a juzgar por el sinnúmero de artículos dedicados a un fenómeno al que muchos han intentado aproximarse sin poder explicarlo nunca. Pero, frente al mito, Jardiel Poncela no se sume en la contemplación ni se pierde en disquisiciones. Lo que le interesa es degradar la imagen del Latin Lover, y es precisamente lo que hace al bautizar a un pez con el nombre del prestigioso actor. Notemos que, si el proceso de animalización es ya de por sí una forma de degradación, la opción de un pez como término comparante enfatiza la intención desmitificadora del autor.

Mudo, inexpresivo, abúlico, el pez no puede llamar la atención más que por su aspecto exterior, su forma y sus colores. Será bonito, eso sí, pero quedará desprovisto de aquel encanto misterioso que tanto fascinaba al público de la época. De ahí que el símil contribuya a vaciar aún más el mito de su sustancia, generando la imagen ridícula de un actor de cine mudo abriendo tontamente la boca en la pantalla como un pez detrás de los cristales de una pecera. Para rematar el proceso desmitificador, el narrador presenta al actor, no solo bajo la forma de un pez, sino como la víctima de una situación lamentable ya que, a la postre, al protagonista de la novela no le cuesta engañar a los «Rodolphus Valentinus» sacando provecho de su instinto gregario y de su falta de criterio para acabar con ellos:

[Zambombo] partió con los dientes una hoja de palmera hasta darle forma de pez y sujetándola con un hilo la tiró al agua. Había observado Zamb que las bandadas de peces seguían siempre la dirección que emprendía el que iba a la cabeza de ellas. El truco consistía, pues, en que los demás peces creyesen que el que dirigía el cotarro era el pez fabricado por Zambombo. [...] Entonces Zamb tiró del hilo, la hojita saltó a la orilla y treinta y seis peces saltaron detrás (Amor: 341).

Hermoso pero tonto y vano, así es como Jardiel Poncela representa a Rodolfo Valentino. Bajo la pluma del autor, el seductor latino resulta desacralizado y desprovisto de su aura mítica. El tratamiento irónico al que se le somete lo derroca del pedestal en que lo tenían puesto sus admiradoras. Así y todo, no es seguro que esta representación del ídolo caído sea capaz de deslustrar el maravilloso recuerdo que conservaban todas aquellas admiradoras que lo conocieron en el apogeo de su fama. Por tanto, al narrador le toca ahora deslucir y vulnerar 
esta imagen radiante del «seductor universal», haciendo mofa de la blancura deslumbradora de sus dientes, el encanto de su mirada aterciopelada, la hermosura de su cuerpo apolíneo que le mereció ser comparado con el Antínoo del Museo de Nápoles (Recqueville, 1978:137).

\section{EL RETRATO DEL LATIN LOVER O EL ARTE DE LA CARICATURA}

Al principio de Pero... ¿hubo alguna vez once mil vírgenes?, el narrador nos propone una descripción del protagonista que, en muchos aspectos, se ajusta al canon de belleza hollywoodiense. Advertimos que el retrato se presenta desde una perspectiva dinámica que remite más a un enfoque cinematográfico que a una descripción literaria. El narrador escoge describir a Valdivia mientras este va bajando lentamente por la escalinata del Círculo de Bellas Artes. La impresión que se desprende de la escena es la de un actor famoso recibiendo el homenaje de su público a la salida de un cine prestigioso durante el estreno de su última película: «Pedro de Valdivia comenzó a bajar la escalinata, de mármol blanco, dulcificada por un tapiz amarillo y negro» (Vírgenes: 135). El efecto de ralentí sugerido por el verbo «comenzar» induce a imaginar a un actor prendado de sí mismo posando para dejarse admirar. Esta impresión viene reforzada por la introducción de una secuencia descriptiva que suspende el movimiento de Valdivia para que «las lectoras pued[a]n contemplarlo ahora a su gusto» (Virgenes: 135). Si se tratase de una película, el cineasta grabaría sin duda el desplazamiento del personaje a cámara lenta antes de congelar la imagen para captar los pormenores del cuerpo y la prestancia de su actor.

Esta pausa no solo provoca una inmovilización del personaje sino que interrumpe también la narración. Parece como si se dilatara el tiempo, puesto que el narrador introduce una larga secuencia descriptiva (de unos veinte renglones) en el desarrollo muy breve de la bajada de la escalinata (apenas unos segundos). Este efecto de suspensión del tiempo de la acción viene subrayado por dos frases simétricas que enmarcan el paréntesis descriptivo. La primera ( «Pedro de Valdivia comenzó a bajar la escalinata») sirve de arranque al retrato y aparece como la imagen invertida de la que cierra el paréntesis ( «Pedro de Valvivia concluyó de bajar la escalinata») que, como se ve, es una oración de sintaxis idéntica pero de contenido semántico opuesto.

Se nota que, al revés de lo que suele pasar en el cine, los efectos de «ralentí» no están al servicio del personaje pues, lejos de participar en el consabido proceso de idealización o de ensoñación, dichos efectos se utilizan aquí con fines desacralizadores. A primera vista, la pausa descriptiva parece encarecer el aspecto físico del seductor, pero advertimos en seguida que sirve ante todo para desprestigiar a Valdivia mediante la introducción en su retrato de una serie de detalles incongruentes. Rostro perfecto, cuerpo escultural, sonrisa deslumbrante, aparentemente el donjuán de Pero... ¿hubo alguna vez once mil vírgenes? reúne en su aspecto exterior todos los atributos del seductor hollywoodiense. Pero el narrador se entretiene degradando sistemáticamente cada una de las cualidades del Latin Lover empezando por la radiante y misteriosa belleza del ídolo.

Uno de los procedimientos de que se vale el autor-narrador consiste en presentar de manera afirmativa una cualidad para negársela, en seguida, al personaje. Este efecto humorístico 
se puede conseguir con una explicación que pretende matizar el retrato pero que, en realidad, lo enmaraña y oscurece. Valdivia «era un hombre guapo - no muy guapo, sino lo bastante poco guapo para resultar guapo-», explica el narrador con mucha seriedad, aunque quizá riendo para sus adentros del desconcierto del lector (Vírgenes: 135). De hecho, siendo lo mejor el enemigo de lo bueno, el exceso de sutileza asesta un golpe fatal al retrato del seductor. El efecto cómico estriba aquí en el principio de reducción al absurdo. Después de enunciar rotundamente un hecho («Valdivia era un hombre guapo»), el narrador se enzarza en una demostración aparentemente sutil pero le da tantas vueltas a la explicación que, en vez sostener la veracidad de su aserción, despierta la incredulidad del lector.

A continuación, para brindarnos un retrato pormenorizado de Valdivia, el narrador se decanta por otra técnica, abandonando la frase retorcida para sacar los mejores efectos humorísticos de la enumeración. A este respecto, dos frases llaman la atención por su construcción similar basada en una antítesis y enfatizada por un ritmo ternario:

Tenía tres cosas negras:

el pelo, los ojos y el smoking.

Tenía también treinta y dos cosas blancas, a saber:

los dientes, colmillos y muelas de su dentadura (Vírgenes: 135-136; énfasis el autor).

En el primer caso, el efecto humorístico estriba en la yuxtaposición de términos de índole distinta, puesto que el narrador coloca en el mismo plano sintáctico elementos que pertenecen al registro de las características físicas esenciales (el color del pelo y de los ojos) junto con otro totalmente exógeno por remitir a un accesorio prescindible, accidental (el smoking). Cabe notar que el narrador resalta esta reunión heteróclita de rasgos recurriendo a la tipografía. La palabra «smoking» aparece como un elemento incongruente en la enumeración por venir escrita con caracteres romanos, diferenciándose así de las otras dos en cursiva. Con esta yuxtaposición, el narrador da al lector la impresión de que el traje de etiqueta es parte integrante del personaje y constituye uno de sus rasgos definitorios como el gesto o el andar. Parece como si Valdivia tuviese que desempeñar para siempre el papel de seductor mundano, un papel que encarna tan perfectamente que llega a afectar a su propia esencia ${ }^{19}$.

En cuanto a la segunda enumeración, su interés estriba paradójicamente en su inutilidad, puesto que nos enteramos de que Valdivia «tenía también treinta y dos cosas blancas, a saber: los dientes, colmillos y muelas de su dentadura» (Vírgenes: 135-136). En este caso, el principio de la frase no es en absoluto enigmático (aunque sí, impreciso) y el lector sustituye automática e inconscientemente la palabra «cosas» por «dientes», exactamente como lo hace el narrador en la explicación que introduce a continuación. Por cierto, este hubiera podido escribir sencillamente: «Tenía treinta y dos cosas blancas, a saber: los dientes». Pues bien,

${ }^{19}$ El narrador recurrirá otra vez a este procedimiento al final de la descripción de don Pedro: «Los hombros anchos; la cintura, estrecha; las pestañas, largas; la documentación, en regla» (Vírgenes: 136). Se tratará entonces de dar al lector la visión de un donjuán que tiene la conciencia limpia, en regla con la administración y la sociedad, muy distinto al personaje transgresor del mito, el cual desafiaba las leyes humanas y quebrantaba todos los tabúes y prohibiciones. 
el efecto humorístico estriba precisamente en la redundancia, puesto que los términos «colmillos» $\mathrm{y}$ «muelas» aparecen como inútiles o por lo menos superfluos. En efecto, si desde el punto de vista lingüístico, la enumeración es pertinente ya que el término «dientes» designa a menudo, de manera elíptica, «los dientes incisivos», aquí la aclaración resulta incongruente puesto que casi todos los lectores interpretarán automáticamente la palabra «dientes» como un término genérico que remite no solo a los incisivos, sino también a los colmillos y muelas.

Para que la enumeración resultase coherente, hubiera sido necesario reducir la extensión semántica de la palabra «dientes» adjuntándole el adjetivo «incisivos» o, al revés, suprimir «dientes» y conservar solo el término «incisivos» usándolo como sustantivo. Por supuesto la elección de una palabra anfibológica no es casual. Confiere al retrato del personaje un aspecto monstruoso, puesto que este parece provisto de una mandíbula que, además de los habituales treinta y dos dientes, ostenta un buen número de muelas y colmillos suplementarios. ¿Cómo subrayar, de manera más eficaz e irónica, la autocomplacencia del personaje, si no es con esos dientes sobrantes que parecen estirar desmedidamente la boca del seductor, estampándole una eterna sonrisa tan petulante como boba?

Además de la dentadura deslumbrante, las pupilas aterciopeladas y la cabellera endrina, el narrador completa el proceso desmitificador con una observación tocante al porte del personaje. Para ello, se vale otra vez del procedimiento de la enumeración con ritmo ternario: «Era alto, esbelto y flexible», pero introduce una variante, ya que completa aquí la descripción con un símil: «como un junco consciente de su oficio» (Vírgenes: 135). Cierto es que la comparación adolece de falta de originalidad ya que es harto común asimilar el cimbreo del cuerpo con el del junco, pero Jardiel Poncela procura revitalizar el cliché gracias al adjetivo «consciente» que teje un lazo intertextual con el «junco pensante» del filósofo Blaise Pascal.

La subversión, igual que en los chistes e historietas, no se verifica hasta el mismo remate de la frase, siendo el adjetivo «consciente» el elemento desencadenante de la disyunción. De hecho, el complemento del adjetivo («de su oficio») es el que permite destruir el tópico para mejor reelaborarlo. El paso del campo de la abstracción («el hombre es un junco pensante») al de la realidad concreta («Don Pedro es un hombre consciente de su oficio») desplaza la imagen hacia el terreno de lo vulgar y pedestre. De este modo, el seductor de encanto devastador viene relegado a rango de profesional del amor, concienzudo, deseoso de cumplir con su deber. Derrocado de su pedestal, el ídolo no es más que una especie de estratega de las alcobas que ejerce el oficio de «seductor de damas a domicilio», como menciona su tarjeta de visita:

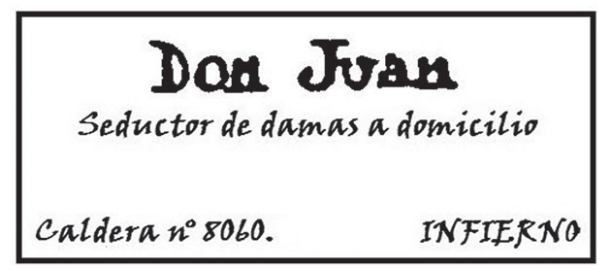

Figura 4. (Vírgenes: 79). 


\section{CONCLUSIÓN}

En su trilogía novelesca, Enrique Jardiel Poncela deja constancia de la fascinación del público por el cine de la época y, especialmente, por esa portentosa máquina hollywoodiense que alimentaba los sueños y las fantasías eróticas de los espectadores. Entre los nuevos tipos cinematográficos puestos de moda por la industria cinematográfica, el personaje del Latin Lover de mirada envolvente y sonrisa deslumbradora no deja de incomodar sobremanera al escritor madrileño. Por eso, a lo largo de la trilogía, Jardiel echa mano de las señales distintivas de este nuevo mito (multitud de admiradores, comportamientos histéricos, aluvión de cartas diarias y declaraciones de amor) para deslucir la imagen de sus representantes más famosos y poner en solfa los mecanismos del Star System. Entre los Latin Lovers más conocidos y celebrados sobresale la figura de Rodolfo Valentino, el «amante universal», por el que Jardiel Poncela no disimula su animadversión ${ }^{20}$. Para desahogarse zahiriendo a un personaje al que designa como el parangón de la cursilería, el autor se vale de todas las potencialidades del humor, esgrimiendo la ironía, el sarcasmo y la caricatura como armas para hacer volar en pedazos la estatua del ídolo. Es más, tratándose de Valentino, Jardiel Poncela vuelve la mirada hacia el cine mudo cómico y las hilarantes parodias realizadas por Stan Laurel y sobre todo Mack Sennett, uno de los más celebrados maestros del género burlesco, quien ejerció una profunda influencia en los escritores de los años veinte, especialmente en los humoristas.

En su análisis de las nuevas corrientes literarias que aparecieron a principios del siglo XX para brindar soluciones a la crisis de la novela, que habían diagnosticado algunos intelectuales tan prestigiosos como el filósofo José Ortega y Gasset ${ }^{21}$, Isabel Criado señala que «deben incluirse [...] novelas que desmitifican mitos o leyendas» (Criado, 1991:7). Por supuesto, prosigue la estudiosa española, «el retorno al mito e, incluso, la desmitificación, en cuanto objeto y proceso literarios, son muy viejos», pero —añade ella- a principios de siglo, se asiste a «una fuerte intensificación» del fenómeno que se enmarca dentro de la corriente de las vanguardias (Criado, 1991:8). Lo que fascina particularmente a los escritores es la idea de que el mito «contribuye a la subversión del modelo realista en cuanto que elemento 'desrealizador', lúdico y atemporal» (Pino, 1998:260). No cabe duda de que la trilogía novelesca de Enrique Jardiel Poncela, escrita a finales de los años veinte con el propósito de dinamitar los viejos modelos decimonónicos, valiéndose de la parodia y echando mano de los recursos que le aportaban unos nuevos medios artísticos como el cine, se inscribe dentro de la corriente de renovación de la narrativa de principios del siglo $\mathrm{xx}$.

${ }^{20}$ Este tipo acabado de seductor hollywoodiense llega casi a obsesionarle puesto que, ya un año antes de emprender la redacción de la trilogía, el autor había publicado un libro de cuentos titulado Pirulís de la Habana, en cuyo prólogo aludía a Valentino al que definía como «el actor más malo de fama más buena» y con el que se comparaba irónicamente: «Se tenía la idea de encabezar estos cuentos con un retrato. Guardo uno precioso, en el cual mis facciones se acercan a las de Rodolfo Valentino [...]» (Jardiel 2001:9).

21 «En suma, creo que el género novela, si no está irremediablemente agotado, se halla, de cierto, en su período último» (Ortega y Gasset, 1995:19). 


\section{REFERENCIAS BIBLIOGRÁFICAS}

Ayala, Francisco, (1996): El escritor y el cine, Madrid, Cátedra, «Signo E IMAgen».

Bosseno, Christian-Marc; Jacques Gerskenkorn, (1992): Hollywood, l'usine à rêves, Paris, Gallimard, «Découvertes».

Criado, IsAbel, (1991): «De El movimiento V.P. a Pero... ¿hubo alguna vez once mil vírgenes?», Ínsula 529: 7-8.

François, CÉcIle, (2013): «La deformación paródica del Catálogo de Don Juan en Pero... ¿hubo alguna vez once mil vírgenes? de Enrique Jardiel Poncela», Echo des études romanes IX, 1, 2013: 119-132.

Jardiel Poncela, EnriQue, (1990): Amor se escribe sin hache, Edición de Roberto Pérez, Madrid, Cátedra.

- (1992): ¡Espérame en Siberia, vida mía!, Edición de Roberto Pérez, Madrid, Cátedra.

- (1988): Pero... ¿hubo alguna vez once mil vírgenes?, Edición de Luis Alemany, Madrid, Cátedra.

- (2001): Pirulís de la Habana (Lecturas para analfabetos), Madrid, Editorial Biblioteca Nueva, «Literatura de humor».

Mañas Martínez, María del Mar, (1997): «El concepto de Hollywood en algunos textos y experimentos vanguardistas de Jardiel: la reflexión metacinematográfica», Dicenda, Cuadernos de Filología Hispánica 15, Madrid, UCM: 229-249.

Marañón, Gregorio, (1958): Don Juan et le donjuanisme, Paris, Gallimard.

Morris, BriAn C, (1993): La acogedora oscuridad. El cine y los escritores españoles (1920-1936), Córdoba, Filmoteca de Andalucía, «Aguaspejo» 3.

Ortega y Gasset, José, (1995): Ideas sobre el Teatro y la Novela, Madrid, Alianza Editorial.

PINO, José MARÍA DEL, (1998): «Novela y vanguardia artística (1923-1934)», en Pérez Bazo, Javier, La Vanguardia en España. Arte y Literatura, Paris-Toulouse, C.R.I.C. \& Ophrys: 251-274.

RecQueville, Jeanne De, (1978): Rudolph Valentino, Paris, Editions France-Empire.

Rougemont, Denis, (1972): L'Amour et l'Occident, Paris, Plon.

Tessé, Jean-Philippe, (2007): Le Burlesque, Paris, Les Cahiers du Cinéma.

Utrera, RAFAel, (1985): Escritores y cinema en España. Un acercamiento histórico, Madrid, Ediciones JC., «Imágenes» 6.

Walker, AleXAnder, (1977): Rudolph Valentino, Paris, Editions Henri Veyrier. 